\title{
Teachers Falling off the Cliff Affordances and Constraints of Social Media in School
}

\author{
Annika Andersson \\ Örebro University \\ annika.andersson@oru.se
}

\author{
Karin Hedström \\ Örebro University \\ karin.hedstrom@oru.se
}

\author{
$\underline{\text { Steffi Siegert }}$ \\ Södertörn University \\ steffi.siegert@sh.se
}

\author{
Carl-Johan Sommar \\ Linköping University \\ carl- \\ johan.sommar@liu.se
}

\begin{abstract}
In a digitalized society our work environment is highly integrated with our home environment making work boundless both in terms of time and space. The digital work environment risks increased stress. Based on a case study in Swedish schools we investigate how teachers experience the use of social media for work-related purposes. We do so by using the Technology Affordance and Constraints Theory to capture the affordances as well as constraints of this use. Findings show that affordances of social media in schools were increased opportunities for learning, transparency and community building. Constraints were distractions from learning, increased isolation, stress and, above all, lack of guidance in how and when to use social media. We end the paper arguing that lack of policies and guidelines governing the use of social media at work is risking an increase in boundary blurring and potentially more stress.
\end{abstract}

\section{Introduction}

Our work environment is highly integrated with our home environment. The use of mobile phones and computers means that the boundary between home and work is gradually blurred - we can work where we want and when we want; the work becomes boundless both in terms of time and space [1]. The digital work environment with the risks it poses for increased stress and influence on psychosocial factors is therefore always present [2]. Siegert and Löwstedt [3] show in their study that employees at workplaces lacking policies or guidelines governing the use of social media at work risked an increase in boundaryblurring and potentially more stress. It is therefore important to understand how to develop and maintain a sustainable digital work environment when introducing new technology and when using existing technology [4]. Organizations, leaders and policy actors need more knowledge in order to manage the digitalization of working life and its impacts responsibly [1], and to reduce negative consequences of the increasingly blurred boundaries between work and private life. These changes are not unambiguously good or bad, which means that studies that problematize and contextualize the changes that digitalization entails in our workplaces are needed. Furthermore, individuals regard the potential of IT to blur boundaries between work and private life as either an opportunity or a risk [5]. One way to understand the impact of digitalization on work life and the working environment is the individual's ability to balance work requirements as part of the whole life puzzle, with the boundary between working life and private life as a central issue [3].

In an environment such as a school, gathering many young people who to a great part socialize using different types of social media, the issue of a sustainable digital work environment becomes important. Learning technologies are said to be able to improve education in many ways, e.g., facilitate the delivery of education, improve the learning process, support more interaction, increase technology proficiency and reduce the teachers' workload [6, 7]. In schools there is a debate about whether using social media in education is beneficial or detrimental for learning [8-10]. Research has pointed to how the use of social media in schools enhances learning [11], how it positively affects the formation and maintenance of social capital and psychological well-being [12], support the making and keeping of friends [13] and how students informally use social media for learning [14]. Other researchers claim that using social media improves students' generic skills such as critical thinking and creativity and supporting identity formation $[8,15]$. On the other side, other researchers emphasize the distraction factor of social 
media making students focus less on what is going on in the classroom [16-18], or that students have difficulties assessing information online [13, 19]. One study [20] found that Facebook users had lower grades and spent fewer hours per week studying compared to non-users.

We therefore consider it important to develop knowledge about teachers' use of social media in schools and its impact on the digital work environment in order to support governance, management of social media and its use in schools. This is also supported by the Swedish Association of Local Authorities and Regions [21, p. 27], who, in their action plan for the school's digitalization, write: "Examples of research demanded are... how digitalization affects the working environment and well-being of children, pupils and staff, and how preschool teachers, teachers and principals and preschool managers' digital skills are identified and developed." Therefore, practiceoriented research is needed to better understand this complexity and how digitalization is changing our workplaces [1].

We have chosen to focus on teachers' experiences of social media since we are interested in social media from a work-place perspective, i.e., how teachers themselves use social media for teaching and/or communication and how students' use of social media affects the teachers' work environment. We do so by using the Technology Affordance and Constraints Theory (TACT) [22] to capture the experienced affordances, or possibilities, and constraints with social media in school. Drawing on a longitudinal 3-year study in Swedish schools using IT and social media, the aim of this paper is to present which affordances and constraints teachers experience when using social media in school. To understand the role of social media in schools, within the framework of technology affordances and constraints, we ask ourselves which affordances and constraints teachers experience when using social media.

\subsection{The Swedish education system}

The Swedish education system provides universal access to education and is entirely funded through the redistribution of municipal taxes to local schools. Reforms stressing privatization and decentralization of the education sector during the 1990s promoted the marketization of education while also allowing for greater degrees of freedom to adapt school organizations to better suit local conditions [23]. Using the market as a role model, the reforms have resulted in a dispersed multi-actor education system in which school governance and the provisioning of preprimary to upper secondary education, including vo- cational training, rest on 290 municipal governments combined with a wide variety of private actors. Currently, $17 \%$ of the primary schools and $33 \%$ of the secondary schools in Sweden are privately managed [24]. Together, the municipal and private schools bear the primary responsibility for providing education to all citizens (SFS 2010:800).

As the majority of welfare service-provisioning is fully funded and partly provided by Swedish municipalities, the national government ensures that education providers meet equal rights and responsibilities, and adhere to national standards, goals and targets [25]. At the same time, the system ensures that grassroot-bureaucrats such as teachers [26] can design the activities at the individual school in such a way that the students are given the conditions to achieve the state-mandated learning objectives.

As a result, teachers and school leaders are caught in a dilemma between having a decentralized responsibility for teaching activities and, at the same time, being subjected to centrally formulated rights and obligations [23]. It is therefore essential to pay attention to what happens when new social practices occur at the micro level as the use of social media within schools is mostly unregulated. Consequently, the situation can give rise to a lack or pruning of workplace policies by shifting the responsibilities to the educationalists.

\section{Affordances of social media use in school}

Social media are, broadly described, web sites and internet-based applications where users create and share content [27]. Social media have permeated our society, and the educational sector is no exception. One of the earliest web-based applications, blogs, focused on user-created content, and can therefore be considered an early form of social media [27]. Blogs allow users to write, read and comment and therefore work on several dimensions of educational interest, e.g., individual self-expression, individual reflection when reading, and collective reflective dialogue [28]. Classroom blogs are used as a communication space that teachers and students can use to share documents and ideas, discuss, comment and reflect [29] and foster a sense of community [30].

However, previous research about using social media in schools point out that social media's (in this case Twitter) effect on teaching practices and student learning outcome is indecisive [31]. This observation makes it even more important to continue studying social media and its role in today's educational practices. 
Social media is part of many teachers' and learners' everyday lives, and teachers use social media in teaching and communicating with their students [32]. Despite this, and in line with Siegert's and Löwstedt's findings [3], teachers in our investigated schools state little, or no, guidance for their digital work environment. Recent research on social media in schools [11, p. 178] points out that despite "an increasingly robust body of research on social media in education, only limited work translates this research into educational practices and policies". This should be seen in relation to the fact that the Swedish School Inspectorate's review of abusive treatment online shows that promotion and prevention work is needed to improve younger learners' digital work environments [32], which is directly related to the teachers' digital work environment. The fact that teachers and school leaders in Sweden experience a lot of stress is supported by statistics from AFA Insurance [33] showing that there were about 2,600 new sickness cases/monthly allowances in 2016. In addition to a great suffering for the individual, this is also associated with high costs and risks of reduced quality in education due to sick leave with temporary staff as a result.

When policies and guidelines are lacking, the responsibility for managing the boundary between work and home is placed on the individual $[5,34]$. This is in line with Håkansta and Bergman [1] who notice that the responsibility for organizational work environment issues often are placed on the individual employee. This is particularly problematic concerning social media - originally used to create and maintain personal relationships - but now increasingly integrated with work. This integration is caused by employers encouraging employees to communicate work-relevant issues using their private social media channels or individuals who follow their work organizations' or colleagues' social media accounts. An important starting point is that social media, being a digital technology, is integrated and embedded in different socio-organizational contexts [35] where digital technology influences and is influenced by underlying political, social and organizational norms [36]. In this way, digitalization points to much more complex relationships than if technology is regarded as an isolated artifact. Thus, social media is part of a so-called social organization of work with demands for collaboration, networking and social skills, which can collide with demands for productivity and contribute to stress and difficulties for recovery [5]. Simultaneously, the private self becomes increasingly visible in professional contexts as employees use their private social media in their work [3] or have to cope with the emotional demands that the workplace may impose on them [37, 38].

The positive effects of digitalization on the individual's work environment, such as the ability to successfully combine private and working life, depend on the individual's ability to use strategies that "reduce friction between different areas of life" [39, p. 17]. In previous studies, these strategies have been described as a continuum between segmentation and integration [40-42], where the perception of what constitutes a functional boundary is perceived differently by different individuals. To facilitate a functional boundary, it is important to have clear agreements and conditions that support the individual's ability to effectively manage the boundary between work and private life [3, 43], making governance and leadership central to a functioning digital and bordercrossing work environment [43]. Social media leadership has been examined in relation to crisis management [44] and organizational change [45], but knowledge of sustainable leadership for social media use is still limited.

\section{Affordance theory and TACT}

An important analytical focus in this study is the possibilities of technology [46] and the boundaries between the private sphere and working life [40]. To this end we adopt the Technology Affordance and Constraints Theory (TACT) as social media has certain properties ("affordances") [46, 47], which can lead to increased stress [47].

TACT is an elaboration of Affordance theory which describes the interaction between a human being and its surrounding environment. According to Gibson [48], human beings, as actors, perceive and behave in the environment, and it is the conditions that enable this interaction that is of interest for the analysis. These conditions include both the properties of the actors and the environment. Affordances exist as a relationship between an actor and an artifact - in our case the artifact of social media. Affordances are the possible actions of the artifact that set the preconditions for an activity but does not stipulate the occurrence of a specific activity.

Gibson [48] uses the example of a brink of a cliff to demonstrate how it can entail both positive and negative affordances: "consider the brink of a cliff. On the one side it affords walking along, locomotion, whereas on the other it affords falling off, injury. [...] Note that all these benefits and injuries, these safeties and dangers, these positive and negative affordances are properties of things taken with reference to an observer but not properties of the experiences of the observer." [48, p. 137] 
Recent research using Affordance theory has further emphasized the constraining aspects of technology use [e.g., 49, 50]. TACT [22] also allow for the investigation of constraints of a particular technology. This is important as the use of technology also constrains the actor [51]. It is important to note that constraints should not be seen as properties of the technology; a constraint can also arise when a technology that once fulfilled the user's needs later is perceived as a constraint to achieve goals [52].

The use of Affordance theory is considered very promising in explaining the consequences of IT artifact use in organizations and related organizational changes [54]. Dini et al. [49] examined an information system's action potentials, constraining factors, and effects through the lens of the technology affordances theory. Wahid and Sæbø [50] used the theory to investigate an Indonesian eParticipation project, identifying affordance perceptions, enabling and inhibiting factors, actualized affordances and affordances effects.

Of particular interest for this study is where the affordance lens has been used to understand the adoption and use of social media. For example, Treem and Leonardi [46] demonstrated how social media is important to organizational communication processes "because they afford behaviors that were difficult or impossible to achieve in combination before these new technologies entered the workplace." They uncovered four relatively consistent affordances enabled by social media: Visibility, persistence, editability, and association. And lastly, Hellström \& Jacob [53] described how Affordance theory has been used to show how different affordances associated with social media use supported knowledge sharing or how social media choices made by users affected social interaction.

\section{Method}

This study is based on a longitudinal, interpretive case study $[54,55]$. The case study methodology was chosen because it is well suited to answer both the how and why questions enabling us to generate theory from practice [56]. Case studies mean that we study a phenomenon in its natural setting while using multiple data collecting methods or respondent groups to validate our findings [56]. The case study being interpretive means that we "[...] attempt to understand phenomena through accessing the meanings that participants assign to them" [57] instead of having as a goal to generate truths [55].

\subsection{Case description}

This study is based on the findings of a 3-year research project that studied Swedish schools that had provided each student with a laptop. Today most Swedish schools provide free laptops or iPads to their students from the age of six until they leave upper secondary level. As of this year (2020) 286 of Sweden's 290 municipalities have reported that they have started implementing one-laptop-per-child solutions for their schools [57]. The reasons for implementing one-laptop-per-child in schools are to prepare the students for a future learning environment and to make use of anticipated pedagogical opportunities.

The participating schools in the project ranged from compulsory schools (ages 4-16) to upper secondary level (ages 16-19). Most of the schools had recently equipped their students with laptops, but some had been doing so for several years, as long back as 2007.

\subsection{Data collection}

Data were collected using surveys, interviews and social media analyses over the three years that the schools participated in the project. Whereas the study covered numerous issues relating to computers being used in schools (e.g., students' results, leadership involvement, and parent communication), in this paper we focus on teachers' experiences of social media use. When first collecting the data, we did not do so with the theory TACT in mind, but this theory came into play when we were re-analyzing the material for this particular study where we have singled out the social media phenomena.

An online survey was conducted on Survey Monkey. The survey contained both closed and openended questions developed from current literature on the topic. Even though 23 schools participated in the study, we chose to only include three schools - two compulsory schools and one higher secondary level school for the quantitative measures in the survey data. These three schools were chosen because of good response rates (55\% on average). For the qualitative data collected in the survey and interviews we included the full range of participating schools. To be clear -3 schools were singled out for the quantitative measures whereas we used open comments (qualitative data) from all schools.

The survey was complemented with focus group interviews with schools that volunteered for this. Fourteen teachers in groups of 3-4 participants and lasted between 40-60 minutes. Teachers were chosen based on their willingness to participate during our visits to the three schools. The interviews were semi- 
structured and revolved around general themes such as benefits and constraints with using laptops and different software (including social media) in schools.

We also analyzed four social media blogs. Users of these blogs were four teachers and 100 students and subjects for the intended discussions were social science, languages, and mathematics. We downloaded a total of 1,098 posts and 164 comments from the four sites. In addition to analyzing the discussions on these sites, we conducted hour-long interviews with the four teachers that managed the blogs.

Table 1. Data collection

\begin{tabular}{|l|l|l|}
\hline $\begin{array}{l}\text { Data collection } \\
\text { type }\end{array}$ & Time & Respondents (n) \\
\hline Survey (online) & $\begin{array}{l}2011, \\
2012, \\
2013\end{array}$ & Teachers (243) \\
\hline $\begin{array}{l}\text { Focus group in- } \\
\text { terviews (at site) }\end{array}$ & 2013 & Teachers (14) \\
\hline $\begin{array}{l}\text { Social media } \\
\text { posts }\end{array}$ & 2011, & $\begin{array}{l}\text { Teachers (4) and } \\
\text { students (100) }\end{array}$ \\
\hline
\end{tabular}

\subsection{Analyzing affordances and constraints}

For the surveys, we used both quantitative and qualitative analysis methods. Quantitative analyses were used to estimate the distribution of affordances and constraints related to this use. Open answers in the surveys and the interview transcripts were analyzed to deeper understand the nature of these affordances and constraints. More specifically, we carried out a thematic analysis [59] where we read through all the data and looked for key themes (i.e., what are teachers talking about when discussing social media?). This gave us a first broad set of categories to work with.

Additional qualitative analyses were used for the social media posts. These posts were inductively analyzed based on color-codes, e.g., we used green color for use of social media to recap what had happened during class and yellow for community-building. Since there were so many blog posts, for this part we used a qualitative data analysis tool (Atlas.ti).

For the analysis of affordances, we relied on TACT where we searched for occurrences where teachers are describing which affordances (e.g., increased collaboration) and constraints (e.g., increased stress) they experience when using social media. We started with qualitative data analysis by reading the open-ended comments in the surveys, the interview transcripts and blog entries to gain familiarity with the material and to develop initial ideas, or themes, for the continued coding process. During the continued coding we organized the data into categories (e.g., "stress", "learning", "no guidelines") and established meaning for each of the categories. Finally, we used these categories to describe a set of affordances and constraints identified as challenges in using social media in schools. Quantitative analyses were also made when we counted on how frequently the teachers addressed a certain issue. The first author conducted all qualitative analyses and was assisted by a colleague with the quantitative analyses.

\section{Affordances and constraints in teach- ers' social media use in school}

The analysis of affordances and constraints related to social media use in Swedish schools shows that teachers mainly identified constraints to learning when students used social media privately during school-hours instead of paying attention to what was going on in the classroom. Teachers also found that being available after school hours was stressful due to an increase in availability. Affordances of social media use were increased accessibility, increased learning, and collaboration outside the classroom. We will go through all aspects experienced in more detail below.

\subsection{Affordances of social media in schools}

\section{Availability}

Contact between students and teachers increased during the three years of investigation. In our surveys, we found that $34 \%$ of the students and $17 \%$ of the teachers said that students reached out to teachers outside school hours at least once a week to discuss school-related matters. This may not sound as such a high number but compared to before schools were using computers and social media this is definitely an increase in contact and teacher accessibility. Most teachers, however, found this new accessibility to be a positive affordance. As one teacher expressed it: "It is really good to be able to communicate online with immigrants using translation software. I really like being able to be in contact with students and parents at any time I please" (Interview with teacher, compulsory school)

\section{Learning}

When talking about social media in positive ways, most teachers refer to their use of Facebook groups and class blogs for learning activities, e.g.: 
"Social media has provided us with new tools for teaching... or learning. It is easy to start large projects and include factual texts, especially factual texts, and discuss at the same time." (Interview with teacher, upper secondary level)

From the analysis of blogs, we found that the vast majority of the posts analyzed were of teachers using the blog to inform and instruct: the teachers posted assignments, recaps of previous lessons, and lesson plans for coming lessons. A large number of the studied blog posts were used to recapitulate what had been done in the previous lesson and to preview the plan for the next lesson. These posts often took the form of a recap-paragraph, preview-paragraph, e.g., "The class was given some time to read and discuss the questions for the text. [...] Next time we'll finish the list and focus on states as actors" (Class Blog 1, August 8, 2011).

The second most common blog-use found in the blog-study (216 instances), was the use of blogs to post supplemental material: this included links to websites (e.g., Wikipedia, online encyclopedias, newspapers), as well as documents containing more in-depth descriptions.

\section{Transparency}

According to teachers, social media afforded a greater degree of transparency. Teachers at the schools we studied used their class blogs to explain grading criteria, course syllabi, and other administrative tasks. One post titled "A long-winding explanation of the criteria for the film analysis" explains in detail the requirements for different grades:

"Pass: The student sees and understands excerpts and whole films about ancient Rome and explicates connections and differences. Only the first part, emphasized [sic] of this criterion is applicable for this assignment" (Class Blog 2, September 2, 2011)

\section{Affordance of community building}

When teachers talk about affordances with social media use, they often refer to the community building it can enable. From our open survey comments, we read statements such as:

"It is very good to use social media such as Facebook for building relations. Our Polish teacher started a FB-group with his class and then they added a class in Poland which they were to visit later that year. In this way teachers and students got to know each other before the physical trip." (Open comment in survey, teacher, compulsory school).

In the blog analysis we categorized 68 posts as community building since these posts addressed the school class, and what the class shared as a whole unit, more informally. We found quite a large number of what we call social statements in teachers' blog posts - statements about informal, social relationships between teachers and students. This includes everything from information about class trips to teachers thanking or praising the students for their work or encouraging them to try harder.

Whereas community building concerns the building or strengthening of connections between students, the social statements we found in the blogs have more to do with the teacher-student relationship. An example of this relationship-building is a post of a personal character relating to the pregnancy of a teacher. "I am not coming into class this afternoon because I am soon officially classified as a zombie. You may have noticed that I have had an even shorter temper than usual... and I think it is best to look after myself before I also alienate (look up the word) you lot! Lots of hormones $=$ no sleep the last few weeks... SMS:es do not disturb me and in case I am able to sleep the phone is turned off. :- See you next week!" (Class Blog 1, November 18, 2011).This post illustrates the informal and personal characteristics of these social posts.

\subsection{Constraints of social media in schools}

\section{Distraction from learning}

The most frequent teacher comment concerning the constraints with social media use in schools is the distraction from learning that they found students experiencing. When teachers in the 2011 survey's open comments were asked to mention the major constraint to one-laptop-per-child education, $74 \%$ stated distractions such as Facebook. In an openended question in the 2012 survey, teachers where asked to freely comment on any negative consequences they had experienced since introducing onelaptop-per-child, and the most common response again related to distractions when students used social media for non-school-related activities. Additionally, the same survey revealed that $73 \%$ felt that social media to "some" or "high" degree negatively affected teaching and learning. "The students get distracted by the computer. I have had students that put away their computer when it's time for schoolwork because they cannot help themselves from entering sites that distract them - such as Facebook" (Open comment in survey, teacher, upper secondary level)

This was also very apparent during the interviews where all groups discussed Facebook as something negative for the students' learning. 


\section{Social media is not social}

Teachers also reported that the students' use of social media led to changes in how they interact with each other and the teachers. Whereas social media gives the students something to do during breaks, in the open comments of the surveys we found that social media in this way has replaced many face-to-face interactions and that many teachers miss these interactions. During the interviews we found that when the teachers talked about social media, they usually expressed themselves as being up against a giant. During these interviews teachers claimed to lack strategies for "killing the beast" and said that they were giving up. Teachers are competing with social media and social media is stealing the students' attention and time:

"The computers are on all the time and divert the students' attention with its intrusive information from Facebook and other social media that are not schoolrelated and that totally puts all other classroom activities out of business" (Interview with teacher, compulsory school)

The blog analysis also showed that there were very few discussions in the class blogs. We only found two instances of teacher-initiated collaboration and they both concerned how the teachers instruct the students to work together in the same document in GoogleDocs: "[...] at the end of the lesson we started up the group work on the theme "a nation - its goals and means." These documents you find in Google Docs where you can continue working on them in your assigned groups" (Class blog 1, August 27, 2011).

Some teachers also miss face-to-face interactions with the students' parents: "The communication with parents has increased. It is more of a continuous communication now. I still think that it is more rewarding to talk directly with the person. The written, digital communication should only be a complement to physical meetings and not a substitute." (Interview with teacher, upper secondary level).

\section{Stress}

During our three years of investigating the schools, our surveys showed that more than half of the teachers expressed that they experienced negative stress in relation to the use of computers in schools. The major reasons for this stress were said to be the increased speed of teaching and learning and their social media use. "The computer is mainly used for contacts with students and their parents. It's a big stress-factor [...] The major difference now that we have laptops is that there is so much more communi- cation between teachers, students and parents. All of that is digital now" (Interview with teacher, compulsory school)

Some teachers even stated that the most important factor for being successful with computers in school is to manage the time that is spent for contact, e.g., "What we need is well-planned and time-limited thinking for staff, students and their parents. The teachers need clear and sustainable guidelines for this both inside and outside class hours" (Open comment in survey, teacher, upper secondary level)

\section{Lack of guidance}

During the interviews, many teachers said they lacked clear guidance on incorporating computers in their teaching practice, and how to manage social media. When the negative consequences of students getting distracted by social media were discussed, teachers pointed to how the students have to control the use, and find strategies, to manage social media by their own:

"The students do not take responsibility; they look at Facebook instead of working. I ask the students to leave the page and go back to the assignment, but I do not have the energy to nag at them. I think the students are old enough to take responsibility for their own education" (Interview with teacher, upper secondary school).

In the open comments of the surveys, teachers also stress that most students know that their choice to use social media instead of listening to the teacher or doing assignments and homework is detrimental to their learning. The teachers do, however, have difficulties finding strategies to cope with the distraction.

In the interviews, teachers describe how distractions from social media have been difficult to control and the students often have to handle the responsibilities on their own. The general claim in the teachers' statements is about students needing to take responsibility, about how it is "up to you" and that it is the individual's choice. When teachers themselves try to guide the students in their social media use, it most often came down to hard solutions such as blocking social media sites, ordering the student to stop or even confiscating the computer. Most teachers also said that they tried to discuss with the students the importance of staying focused on the learning task and that they were tired of acting as Facebook police officers: "It takes a lot of time from the lessons just having to tell the students to close the computers when they are not to be used, to tell them to leave Facebook etc. I feel powerless - I am a teacher, not a police officer" (Interview with teacher, compulsory school). 


\section{Discussion and Conclusion}

We identified affordances of social media relating to increased opportunities for learning, transparency and community building. Teachers use social media to inform and instruct. This increase in communication also afforded a greater degree of transparency where teachers can explain e.g., grading criteria. This is in line with the research findings of Treem and Leonardi [45] demonstrating how social media is important for organizational communication processes, and Hellström \& Jacob [53] describing how different affordances associated with the use of social media supported knowledge sharing and affected social interaction. Another affordance of teachers' social media use is community building where social media was used for social statements in a more informal way - just as has been described by previous research [e.g., 29]

Constraints of social media in schools were mainly related to distractions from learning, increased isolation, stress and, above all, lack of guidance in how and when to use social media. We believe that constraints related to distractions, stress and students working more in (physical) isolation could be prevented, at least to a large degree, if guidelines and rules were in place for social media use. Teachers were lacking guidance from school management on how to work with social media constructively and in a sustainable way. In our material, we found that teachers tried different strategies such as blocking or monitoring social media use. Other teachers left the responsibility to the students - where it could be questioned how much choice it is reasonable to place on children and young people given the responsibility that comes with it. The picture that emerges from our material is that teachers and students try to solve the problems independently due to a lack of guidance from leaders or heads of school. Some teachers even stated that the most important factor for being successful with social media use is by managing the time that is spent for contact. As one teacher expressed:

"What we need is well-planned and time-limited thinking for staff, students and their parents. The teachers need clear and sustainable guidelines for this both inside and outside class hours" (Interview with teacher, upper secondary level)

As both empirical knowledge is needed on how employees use different technology strategies to manage social media [60], and increased researchbased knowledge on the impact of digitalization on the work environment [1], our study contributes by highlighting sets of active affordances and constrains to provide a deeper understanding of how social media impact the work life of educationalists.

To support teachers' active boundary management [see also 60], a concrete and practical result would be a framework for managing and controlling a sustainable digital work environment in the schools. Such research results can constitute an important response to the sub-goals regarding the impact of digitalization on teaching and learning, and to follow-up on the digitization work in schools that the Swedish Association of Local Authorities and Regions has set out in its national action plan [21]. Social media is integrated and embedded in different socioorganizational contexts - in this case the workplace, school and home of teachers and students - and all of these contexts have to be considered when creating guidelines for social media use.

An obvious limitation to this study is that the data collection took place some 6-7 years ago, during the early days of the one-laptop-per-child-initiative in Sweden. Social media use in schools was still in its infancy and new social media (e.g., Instagram, Snapchat) have entered the schools. We know from our contacts in schools that the use of social media has increased and that there is still a lack of guidelines for teachers in Swedish schools. Recent research (e.g., [11]) confirms this picture and discusses implication for educational policy. Future research should synthesize the latest research on social media in schools and collect up-dated empirical data on teachers' experiences of social media use in their work environment. Without guidance in these matters, we may risk having increasingly more teachers falling off the cliff.

\section{References}

[1] C. Håkansta and A. Bergman, "Digitaliserad och isolerad: yrkespraktiken i ett mobilt yrke," Arbetsmarknad \& Arbetsliv, vol. 24, no. 3-4, pp. 7-25, 2018.

[2] A. t. S. W. E. Authority), "Digital arbetsmiljö (In English: "Digital work environment)," Arbetsmiljöverket, Stockholm, 2015, vol. 2015:17.

[3] S. Siegert and J. Löwstedt, "Online boundary work tactics: an affordance perspective," New Technology, Work and Employment, vol. 34, no. 1, pp. 18-36, 2019.

[4] J. Johansson, M. Holmquist, M. Thomsen, and M. Åkesson, "En god digital arbetsmiljö: Slutrapport," ed, 2018.

[5] N. Gillberg, "Flexibilitet, tillgänglighet och synlighet i det digitaliserade arbetslivets organisering. i G. Aronsson," Gränslöst arbete-En forskarantologi om arbetsmiljöutmaningar i 
anknytning till ett gränslöst arbetsliv, pp. 23-36, 2018.

[6] J. R. Venable, J. Pries-Heje, D. Bunker, and N. L. Russo, "Design and Diffusion of Systems for Human Benefit: Toward More Humanistic Realisation of Information Systems in Society," Information Technology \& People, vol. 24, no. 3, pp. 208-216, 2011, doi: $10.1108 / 09593841111158347$.

[7] J. Lei and Y. Zhao, "One-To-One Computing: What Does it Bring to Schools?," Journal of Educational Computing Research, vol. 39, no. 2, pp. 97-122, 2008.

[8] N. Selwyn, "Faceworking: exploring students' education-related use of Facebook," Learning, Media and Technology, vol. 34, no. 2, pp. 157174, 2009/06/01 2009, doi: $10.1080 / 17439880902923622$.

[9] C. B. Fried, "In-class laptop use and its effects on student learning," Computers \& Education, vol. 50, no. 3, pp. 906-914, 2008, doi: 10.1016/j.compedu.2006.09.006.

[10] N. Selwyn, "Social media in higher education," in The Europa World of Learning 2012, T. E. W. o. Learning Ed., 62nd ed. (The Europa World of Learning. London: Routledge, 2011, p. 2996.

[11] Greenhow C, Galvin SM, Staudt Willet KB. What Should Be the Role of Social Media in Education? Policy Insights from the Behavioral and Brain Sciences. 6(2):178-85, 2019.

[12] N. B. Ellison, C. Steinfield, and C. Lampe, "The Benefits of Facebook "Friends:" Social Capital and College Students' Use of Online Social Network Sites," Journal of Computer-Mediated Communication, vol. 12, no. 4, pp. 1143-1168, 2007, doi: 10.1111/j.1083-6101.2007.00367.x.

[13] M. DeGagne and R. Wolk, "Unwired: Student Use of Technology in the Ubiquitous Computing World," Information Systems Education Journal, vol. 5, no. 13, pp. 3-14, 2007.

[14] C. Madge, J. Meek, J. Wellens, and T. Hooley, "Facebook, social integration and informal learning at university: 'It is more for socialising and talking to friends about work than for actually doing work'," Learning, Media and Technology, vol. 34, no. 2, pp. 141-155, 2009/06/01 2009, doi: $10.1080 / 17439880902923606$.

[15] C. Greenhow and B. Robelia, "Informal learning and identity formation in online social networks," Learning, Media and Technology, vol. 34, no. 2, pp. 119-140, 2009/06/01 2009, doi: $10.1080 / 17439880902923580$.

[16] J. Bjelvenmark, "One to One - a student perspective on computer use in Swedish high school," Bachelor, Behavioural Sciences and Learning, Linköpings universitet, Linköping, LIU-LÄR-L-EX--11/34--SE, 2011.

[17] J. Idebro, "En-till-en-satsning på Vimmery gymnasium (One-to-one-initiative at Vimmerby Upper Secondary School)," Master, Behavioural
Sciences and Learning, Linköping University, Linköping, 2010.

[18] J. Kulesza, G. DeHondt II, and G. Nezlek, "More Technology, Less Learning?," Information Systems Education Journal, vol. 9, no. 7, pp. 413, 2011. [Online]. Available: http://isedj.org/2011-9/

[19] K.-W. Lai and K. Pratt, "Positive to a Degree: The Effects of ICT Use in New Zealand Secondary Schools," Computers in the Schools, vol. 24, no. 3-4, pp. 95-109, 2008/01/18 2008, doi: $10.1300 / \mathrm{J} 025 \mathrm{v} 24 \mathrm{n} 0307$.

[20] P. A. Kirschner and A. C. Karpinski, "Facebook ${ }^{\circledR}$ and academic performance," Computers in Human Behavior, vol. 26, no. 6, pp. 1237-1245, 2010, doi: 10.1016/j.chb.2010.03.024.

[21] SKL, "\#skolDigiplan - Nationell handlingsplan för digitalisering av skolväsendet. ," Sveriges kommuner och landsting, Stockholm, 2019.

[22] A. Majchrzak and M. L. Markus, "Technology affordances and constraints in management information systems (MIS)," Encyclopedia of Management Theory,(Ed: E. Kessler), Sage Publications, Forthcoming, 2012.

[23] M. Jarl and J. Pierre, Skolan som politisk organisation. Gleerups, 2018.

[24] C. Holmström. "Antal friskolor i Sverige (In English: The number of Private schools in Sweden)." Ekonomifakta. https://www.ekonomifakta.se/Fakta/Valfarden-iprivat-regi/Skolan-i-privat-regi/Antal-friskolor-iSverige/ (accessed June 17, 2020).

[25] The School Act (SFS 2010:800), Utbildningsdepartementet, 2010.

[26] M. Lipsky, Street-level bureacracy. New York: Russel Sage Foundation, 1980.

[27] A. M. Kaplan and M. Haenlein, "Users of the world, unite! The challenges and opportunities of Social Media," Business Horizons, vol. 53, no. 1, pp. 59-68, 2010.

[28] L. Deng and A. H. K. Yuen, "Towards a framework for educational affordances of blogs," Computers \& Education, vol. 56, no. 2, pp. 441451, 2011, doi: 10.1016/j.compedu.2010.09.005.

[29] A. L. Luehmann and J. Frink, "How Can Blogging Help Teachers Realize the Goals of Reform-based Science Instruction? A Study of Nine Classroom Blogs," Journal of Science Education and Technology, vol. 18, no. 3, pp. 275-290, 2009.

[30] D. de Almeida Soares, "Understanding class blogs as a tool for language development," Language Teaching Research, vol. 12, no. 4, pp. 517-533, 2008.

[31] J. P. Carpenter and D. G. Krutka, "How and why educators use Twitter: A survey of the field," Journal of research on technology in education, vol. 46, no. 4, pp. 414-434, 2014. 
[32] Skolinspektionen, "Skolors arbete mot trakasserier och kränkande behandling på nätet," 2016.

[33] A. Försäkring, "Allvarliga arbetsskador och långvarig sjukfrånvaro," AFA Försäkring, 2018.

[34] J. Gulliksen, Lantz, A., Walldius, Å., Sandbland, B. \& Åborg, C. , "Digital arbetsmiljö (In English: A Digital Working Environment)," Arbetsmiljöverket, 2015.

[35] K. Hedström, E. Wihlborg, M. Gustafsson and F. Söderström, "Constructing identities professional use of eID in public organisations," Tranforming Government: People, Porcess and Policy, vol. 9, no. 2, pp. 143-158, 2015, doi: 10.1108/TG-11-2013-0049

[36] Woolgar, Steve, and Daniel Neyland. "Mundane governance: How ordinary objects come to matter.", 2013.

[37] G. W. Mearns, R. Richardson, and L. Robson, "Enacting the internet and social media on the public sector's frontline," New Technology, Work and Employment, vol. 30, no. 3, pp. 190-208, 2015.

[38] N. Cohen and J. Richards, "'I didn't feel like I was alone anymore': evaluating self-organised employee coping practices conducted via F acebook," New Technology, Work and Employment, vol. 30, no. 3, pp. 222-236, 2015.

[39] G. Aronsson, "Gränslöst arbete- en introduktion," in "En forskarantologi om arbetsmiljöutmaningar i anknytning till ett gränslöst arbetsliv," Arbetsmiljöverket, 2018.

[40] B. E. Ashforth, G. E. Kreiner, and M. Fugate, "All in a day's work: Boundaries and micro role transitions," Academy of Management review, vol. 25 , no. 3, pp. 472-491, 2000.

[41] C. Nippert-Eng, "Calendars and keys: The classification of "home" and "work"," in Sociological Forum, 1996, vol. 11, no. 3: Springer, pp. 563-582.

[42] G. E. Kreiner, E. C. Hollensbe, and M. L. Sheep, "Balancing borders and bridges: Negotiating the work-home interface via boundary work tactics," Academy of management journal, vol. 52, no. 4, pp. 704-730, 2009.

[43] C. Mellner, "Strategier, gränskontroll och ledarskap i gränslöst arbete," 2018.

[44] D. A. Gruber, R. E. Smerek, M. C. Thomas-Hunt, and E. H. James, "The real-time power of Twitter: Crisis management and leadership in an age of social media," Business Horizons, vol. 58, no. 2, pp. 163-172, 2015.

[45] N. S. Reynolds, "Making sense of new technology during organisational change," New Technology, Work and Employment, vol. 30, no. 2, pp. 145-157, 2015.

[46] J. W. Treem and P. M. Leonardi, "Social media use in organizations: Exploring the affordances of visibility, editability, persistence, and association," Annals of the International
Communication Association, vol. 36, no. 1, pp. 143-189, 2013.

[47] J. Fox and J. J. Moreland, "The dark side of social networking sites: An exploration of the relational and psychological stressors associated with Facebook use and affordances," Computers in human behavior, vol. 45, pp. 168-176, 2015.

[48] J. J. Gibson, "The theory of affordances," Hilldale, USA, vol. 1, no. 2, 1977.

[49] A. A. Dini, F. Wahid, and Ø. Sæbo, "Affordances and constraints of social media use in eParticipation: perspectives from Indonesian politicians," 2016.

[50] F. Wahid and Ø. SæbØ, "Affordances and effects of promoting eParticipation through social media," in International Conference on Electronic Participation, 2015: Springer, pp. 3-14.

[51] P. M. Leonardi, "When flexible routines meet flexible technologies: Affordance, constraint, and the imbrication of human and material agencies," MIS quarterly, pp. 147-167, 2011.

[52] G. Pozzi, F. Pigni, and C. Vitari, "Affordance theory in the IS discipline: A review and synthesis of the literature," 2014.

[53] T. Hellström and M. Jacob, "Policy instrument affordances: a framework for analysis," Policy Studies, vol. 38, no. 6, pp. 604-621, 2017.

[54] G. Walsham, Interpreting Information Systems in Organizations, New York, NY: John Wiley \& Sons, Inc. , 1993. [Online]. Available: http://oss.sagepub.com/cgi/reprint/15/6/937. Accessed on: April 8, 2009.

[55] G. Walsham, "Interpretive Case Studies in IS Research: Nature and Method," European Journal of Information Systems, vol. 4, pp. 74-81, 1995.

[56] I. Benbasat, D. Goldstein, and M. Mead, "The Case Research Strategy in Studies of Information Systems," MIS Quarterly, vol. 11, no. 3, pp. 369387, 1987.

[57] W. Orlikowski and J. J. Baroudi, " Studying Information Technology in Organizations: Research Approaches and Assumptions," Information Systems Research, vol. 2, no. 1, pp. 1-28, 1991.

[58] A. Taawo, M. Davidsson, and P. Becker. "1-1 satsningar i Sverige (in English: 1:1 initiatives in Sweden)." http://bit.ly/egen-dator (accessed 2012-06-19, 2012).

[59] B. J. Oates, Researching Information Systems and Computing. Cornwall: Sage, 2008, p. 341.

[60] A. Ollier-Malaterre, N. P. Rothbard, and J. M. Berg, "When worlds collide in cyberspace: How boundary work in online social networks impacts professional relationships," Academy of Management Review, vol. 38, no. 4, pp. 645-669, 2013. 